\title{
The Relationship Between Government Policy and Financial Performance: A Study on the SMEs in Iraq
}

\author{
Emad Harash \\ Madenat Alelem University College, Baghdad, Iraq \\ Karim Al-Tamimi \\ Madenat Alelem University College, Baghdad, Iraq \\ Suhail Al-Timimi \\ University of Basra, Basra, Iraq
}

\begin{abstract}
The study examined the relationship between government policies and financial performance in small and medium enterprises (SMEs) in Iraq. The study aimed at establishing the relationship between government policies and financial performance of SMEs. In the Republic of Iraq, it is estimated that $99 \%$ of the business entities are SMEs. They also contribute to GDP and provide employment. Notwithstanding the recognition of the important roles SMEs play in Iraq, their development is largely constrained by a number of factors, such as the existence of laws, regulations, and rules that impede the development of the sector. The study provided some relevant recommendations to policy makers, development agencies, entrepreneurs, and SME managers to ascertain the appropriate strategy to improve the SME sector in Iraq.
\end{abstract}

Keywords: government policy, financial performance, small and medium enterprises (SMEs)

\section{Introduction}

Small and medium enterprises (SMEs) are the focus of this study as they are a key economic sector in many countries (Ayyagari, Demirgüç-Kunt, \& Beck, 2003; OECD, 2004). SMEs are the prime mover of economic undertakings (Hak-Su, 2007; Kongolo, 2010; Mukaila Ayanda \& Sidikat Laraba, 2011; Ogechukwu \& Latinwo, 2010). SMEs in developed countries have a higher success rate than developing countries (Onugu, 2005). More evidence suggests that SMEs constitute the major component of the private sector and are the cornerstones for creativity and innovation because they can help raise productivity and introduce innovations; it is estimated to have accounted for between 20 and 40 percent of labour productivity growth in some range of European countries and in the USA (Wamono, Kikabi, \& Mugisha, 2012).

SMEs were selected because they have a significant place in the economy, especially from the point of view of the development of local and regional economies. Literature related to performance of SMEs does not provide a comprehensive explanation for performance these companies. Particularly studies have been focused

Emad Harash, Ph.D., Department of Accounting, Madenat Alelem University College.

Karim Al-Tamimi, Ph.D., Department of Law, Madenat Alelem University College.

Suhail Al-Timimi, Ph.D., College of Admin and Economics, University of Basra.

Correspondence concerning this article should be addressed to Emad Harash, Madenat Alelem University College, Baghdad, Iraq. E-mail: emadharesh@yahoo.com. 
on factors affecting the financial performance of established SMEs (Harash, Fatima, \& Essia, 2013; Mohd Shariff \& Peou, 2008; Mohd Shariff, Peou, \& Ali, 2010). In Iraq a systematic and empirical studies pertaining to the knowledge of how the government policies impact the financial performance of the SMEs sector is a few (Harash et al., 2013).

The main importance is that SMEs have the capacity to create sufficient levels of skilled and semi-skilled employment (Sana \& Abbas, 2005; USAID, 2010). Studies have shown that Iraq consists of a vast number of SMEs which are the main provider of employment for the majority of people. However, SMEs face many problems that affect their financial performance in Iraq such as government policy (Sana \& Abbas, 2005; COS, 2011; USAID, 2010). These studies have shown that SMEs which lacked government support policies have limited access to improving their financial performance.

\section{Financial Performance}

The performance is the result of strategies the firm employs to achieve financial goals (Yamin, Gunasekaran, \& Mavondo, 1999). The level of success of a firm within the SMEs sector is measured through its financial performance based on a selected period of time (Liao \& Wu, 2009). Financial performance is a measure of an organization's financial condition or financial outcomes resulting from management decisions carried out by organization members (Harash, Fatima, \& Essia, 2013). According to Hoque and James (2000), financial performance refers to the level of companies' financial performance relative to their major competitors over the past years. It literally refers to financial measures, such as return equity (ROE), return on investment (ROI), operating profit, and sales growth rate (Chenhall \& Langfield-Smith, 2007; Govindarajan, 1988; Hoque \& James, 2000). Hoque and James (2000) claimed that these indicators are the best to identify whether an organization is doing things right and hence these indicators can be used as the primary measure of organization success. Furthermore, Doyle (1994) pointed profitability as the most common measure of performance in companies. These indicators are considered to be the common measures of financial profitability (Abu-Jarad, Yusof, \& Nikbin, 2010).

Various scholars have attempted to provide a clear definition of performance, but they had yet to come to an agreement over a common definition, particularly regarding some aspects of terminology issues, analytical levels, and the conceptual basis for assessment. Performance of a company can be defined in various ways depending on the questions in mind when inquire about a company's performance (Davis \& Cobb, 2010; Islam, Khan, Obaidullah, \& Alam, 2011; Wheelen \& Hunger, 1995). For example, Stainer (2006) defined performance as "the firm's ability to achieve their objectives, not only in a resourcefully manner but also consistently and, sometimes, by losing sight of the purpose of analyzing it” (p. 254). While, Penrose (1995) argued that performance is an evaluation of the degree and a firm has successfully achieved its goals. Regardless of the differences among researchers on what the definition of performance is, they agree that it is generally associated with expectations for success. The financial performance of SMEs depends on the success of firms in the market, both locally and internationally. Information on financial performance is useful in predicting the capacity of the enterprise hence analyzing how well or poorly an enterprise is doing against its set objectives. Financial performance is commonly used as an indicator of a firm's financial health over a given period of time. This puts financial performance as one of the key issues of SMEs. Therefore, in this study financial performance refers to ROE, ROI, operating profit, and sales growth rate.

The literature review by some researchers in the field of management and SMEs showed much interest in 
researches related to SMEs and economic development (Hak-Su, 2007; Kongolo, 2010; Mukaila Ayanda \& Sidikat Laraba, 2011; Ogechukwu \& Latinwo, 2010) and they discussed various difficulties. Among the problems related to performance, a pertinent question is why only certain SMEs could achieve performance. In comparison there were also SMEs that had failed (Falkena et al., 2002; Abereijo \& Fayomi, 2005; Okpara \& Wynn, 2007; Abor \& Quartey, 2010). The answer to such a dilemma is certainly needed by all governments and stakeholders in the SMEs sector. Some studies attempted to provide the answers by pointing to government policy as a strong influence on performance (Dandago \& Usman, 2011; Keh, Nguyen, \& Nh, 2007; Mohd Shariff, Peou, \& Ali, 2010; Mohd Shariff \& Peou, 2008; OECD, 2009). It was reported by USAID $(2009,2010)$ and Sana and Abbas $(2005)$ that government policies often increase opportunities for SMEs to develop but often developing countries and post conflict countries seldom practice policies which are supportive of the development of SMEs. This may be due to a lack of understanding and access to important information regarding SMEs by decision makers or policy planners in the government (USAID, 2009). Besides, the concern of the government of the day is often to adopt policies that could strengthen their political power leading to less focus on economic development (Sana \& Abbas, 2005). Subsequently, the government policies also left out or failed to address and overcome the hindrances pertaining to the development of SMEs.

\section{Government Policy}

Government policy, positions and guidelines of government, schemes and incentives support systems for the private sector, particularly for the SMEs (Dandago \& Usman, 2011; Mohd Shariff et al., 2010; Mohd Shariff $\&$ Peou, 2008). Many recommendations have emerged from the studies and deliberate efforts are still needed on the part of governments, through its series of efficient policies affecting competition in the market to nurture a climate that is conducive to successful and profitable operations of SMEs (Dandago \& Usman, 2011; Sobri Minai \& Lucky, 2011). These recommendations include the call government to take concrete actions to curb dumping, smuggling and importation of cheap foreign products; reducing corruption practices; providing social justice; providing market information; improvements in infrastructure; providing training for SMEs and encouraging private investment. There are various factors influencing the financial performance of SMEs and most of them are complex and erratic. For example, government can behave an entrepreneurial role to impact the creation of a sustainable market factors. It also can act an entrepreneurial role to impact the creation of a land infrastructure conditions to support SMEs (Nguyen, Alarm, Perry, \& Prajogo, 2009). The results of previous studies (Sana \& Abbas 2005; USAID, 2009, 2010, 2011) indicate that economies in transition (Iraq, for example) need to take some specific measures to establish the conditions to promotion of entrepreneurial activities and for SMEs to create opportunities to grow in different sectors of the economy. The results of studies (Mohd Shariff et al., 2010; Mohd Shariff \& Peou, 2008; Nguyen et al., 2009; Sobri Minai \& Lucky, 2011) also indicate that in the absence of sturdy market forces in these countries transitional economy, the government must play a decisive role to create those conditions. In addition, the previous studies underlined that government policies have an impact on SMEs activities, linkages and networking in order to cooperation and utilizing resources (Brimble, Oldfield, \& Monsakul, 2002; Harvie, 2001, 2002; Tambunan, 2005). Theoretical and empirical studies (Opara, 2010; Mohd Shariff \& Peou, 2008) have shown government policy that seems to be more consistent in influencing the financial performance of the SMEs. In developed and developing countries, government policies that provide support are a critical factor for SMEs growth (Nguyen et al., 2009). The nature 
and scope of government policies have a direct impact on a company's financial performance (Borges, Hoppen, \& Luce, 2009). The supports of government policies for SMEs vary from country to country and from developed countries to developing countries due to differences in culture, the level of industrialization and business contexts (Nguyen et al., 2009). Country governments create the rules and frameworks in which businesses are able to compete against each other. From time to time the government will change these rules and frameworks forcing SMEs to change the way they operate. Financial performance of SMEs is thus keenly affected by government policies. Governments of the day regularly changes laws in line with its political policies. As a result SMEs continually have to respond to changes in the legal framework. These policies can have a major impact on the competitiveness and profitability of SMEs (Araujo, Kjellberg, \& Spencer, 2008; Kjellberg \& Helgesson, 2007; Nguyen et al., 2009; Nugent \& Yhee, 2002).

\section{Contingency Framework}

According to the resource-based view (RBV) framework, government policy is considered as an important variable. This study will attempt to examine the influence of government policy variable on the performances of SMEs. More specifically, the primary objective of the study was to examine empirically the influence of government policy on the financial performance of SMEs in the Iraq. From the resource-based view viewpoint, different types of companies operating in different situations require different government policy. Government policy is normally effective for companies involved in high volume products. Figure 1 presents the research model of the present study.

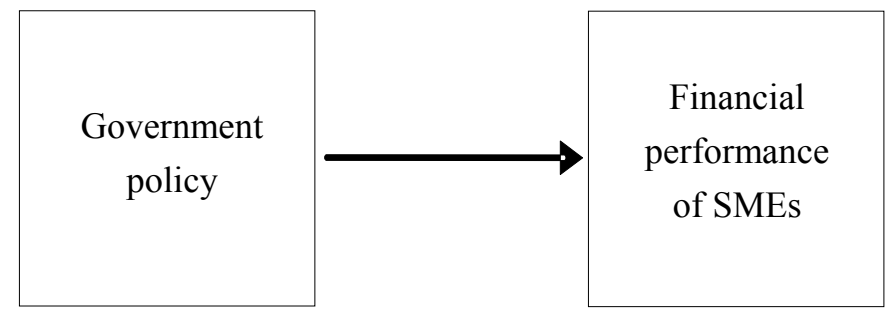

Figure 1. Proposed theoretical framework.

In order to exam the proposed relationships between government policy and financial performance of SMEs, current study developed the following proposition:

The financial performance of SMEs will vary with the choice of government policy adopted.

\section{Conclusions}

SMEs were selected because they have a significant place in the economy, especially from the point of view of the development of local and regional economies. This study was found the relationship between government policy and financial performance of SMEs. In addition, government policy has a major impact on the competitiveness and profitability of SMEs. Conceptually, the study indicates him financial performance of SME varies with the choice of the government policy they adopted. Conceptually, the study indicates the performance of SME varies with the choice of the government policy, positions and guidelines of government, schemes and incentives and support systems for the private sector. This is significant for at least three parties, (i.e., customers, companies, and the relevant authorities' bodies), to strategize on containing the existence of the effect in SMEs by accordingly controlling the selected factors. 


\section{References}

Abereijo, I. O., \& Fayomi, A. O. (2005). Innovative approach to SME financing in Nigeria: A review of small and medium industries equity investment scheme (SMIEIS). J. Soc. Sci., 11(3), 219-227.

Abor, J., \& Quartey, P. (2010). Issues in SME development in Ghana and South Africa. International Research Journal of Finance and Economics, 39, 218-228.

Abu-Jarad, I. Y., Yusof, N., \& Nikbin, D. (2010). A review paper on organizational culture and organizational performance. International Journal of Business and Social Science, 1(3), 26-46.

Araujo, L., Kjellberg, H., \& Spencer, R. (2008). Market practices and forms: Introduction to the special issue. Marketing Theory, 8(1), 5-14.

Ayyagari, M., Demirgüç-Kunt, A., \& Beck, T. (2003). Small and medium enterprises across the globe: A new database. World Bank Policy Research Working Paper No. 3127.

Borges, M., Hoppen, N., \& Luce, F. B. (2009). Information technology impact on market orientation in e-business. Journal of business research, 62(9), 883-890.

Brimble, P., Oldfield, D., \& Monsakul, M. (2002). 8 Policies for SME Recovery in Thailand. The Role of SMEs in National Economies in East Asia, 2, 202.

Chenhall, R. H., \& Langfield-Smith, K. (2007). Multiple perspectives of performance measures. European Management Journal, 25(4), 266-282.

Dandago, K. I., \& Usman, A. Y. (2011). Assessment of government industrialisation policies on promoting the growth of small scale industries in Nigeria. Proceedings from Ben-Africa Conference Zanzibar, Tanzania.

Davis, G. F., \& Cobb, J. A. (2010). Resource dependence theory: Past and future. Research in the Sociology of Organizations, 28, 21-42.

Doyle, P. (1994). Setting business objectives and measuring performance. European Management Journal, 12, 123-132.

Falkena, H., Abedian, I., Von Blottnitz, M., Coovadia, C., Davel, G., Magungandaba, J., ... Rees, S. (2002). SMEs' access to finance in South Africa. Pretoria: The Task Group of the Policy Board for Financial Services and Regulation.

Govindarajan, V. (1988). A contingency approach to strategy implementation at the business-unit level: Integrating administrative mechanisms with strategy. Academy of Management Journal, 31(4), 828-853.

Hak-Su, K. (2007). Small and medium enterprises and ICT. Retrieved from http://www.wasmeinfo.org/Resource/SME\%20and\%20ICT\%20Book.pdf

Harash, E., Fatima, J. A., \& Essia, R. A. (2013). Moderating effect of market practices on the government policy-Performance relationship in Iraq SMEs.Proceedings from 4th Global Conference for Academic Research on Economics, Business and Management (GCAR-EBM). Kuala Lumpur, Malaysia.

Harvie, C. (2001). Competition policy and SMEs in Vietnam. Working paper series 2001, WP 01 10, Department of economic, Department of economic University of Wollongong, 2001.

Harvie, C. (2002). China's SMEs: Their evolution and future prospects in an evolving market economy. Northampton, MA: Edward Elgar.

Hoque, Z., \& James, W. (2000). Linking balanced scorecard measures to size and market factors: Impact on organizational performance. Journal of Management Accounting Research, 12, 1-18.

Islam, M. A., Khan, M. A., Obaidullah, A. Z. M., \& Alam, M. S. (2011). Effect of entrepreneur and firm characteristics on the business success of small and medium enterprises (SMEs) in Bangladesh. International Journal of Business and Management, 6(3), 289

Keh, H. T. Nguyen, T. T. M., \& Ng, H. P. (2007). The effects of entrepreneurial orientation and marketing information on the performance of SMEs. Journal of Business Venturing, 22(4), 592-611.

Kjellberg, H., \& Helgesson, C. F. (2006). Multiple versions of markets: Multiplicity and performativity in market practice. Industrial Marketing Management, 35(7), 839-855.

Kjellberg, H., \& Helgesson, C. F. (2007). On the nature of markets and their practices. Marketing Theory, 7(2), 137-162.

Kongolo, M. (2010). Job creation versus job shedding and the role of SMEs in economic development. African Journal of Business Management, 4(11), 2288-2295.

Liao, S. H., \& Wu, C. C. (2009). The relationship among knowledge management, organizational learning, and organizational performance. International Journal of Business and Management, 4(4), 64-76. 
Mohd Shariff, M. N. M., \& Peou, C. (2008). The relationship of entrepreneurial values, firm financing and the management and growth performance of small-medium enterprises in Cambodia. Problems and Perspectives in Management, 6(4), 55-64.

Mohd Shariff, M. N., Peou, C., \& Ali, J. (2010). Moderating effect of government policy on entrepreneurship and growth performance of small-medium enterprises in Cambodia. International Journal of Business and Management Science, 3(1), 57.

Mukaila Ayanda, A., \& Sidikat Laraba, A. (2011). Small and medium scale enterprises as a survival strategy for employment generation in Nigeria. Journal of Sustainable Development, 4(1), 200.

Nguyen, T. H., Alam, Q., Perry, M., \& Prajogo, D. (2009). The entrepreneurial role of the state and SME growth in Vietnam. Journal of Administration \& Governance, 4(1), 60-71.

Nugent, J. B., \& Yhee, S. J. (2002). Small and medium enterprises in Korea: Achievements, constraints and policy issues. Small Business Economics, 18(1), 85-119.

Ogechukwu, A. D., \& Latinwo, H. (2010). Entrepreneurial developments and small scale industry contribution to Nigerian national development-A marketing interface. Information Management and Business Review, 1(2), 51-68.

Okpara, J. O., \& Wynn, P. (2007). Determinants of small business growth constraints in a sub-Saharan African economy. SAM Advanced Management Journal, 72(2), 24.

Onugu, B. A. N. (2005). Small and medium enterprises (SMEs) in Nigeria: Problems and prospects (Unpublished Dissertation for a Doctor of Philosophy in Management Award, St. Clements University, Nigeria).

Opara, B. C. (2010). Prospects of marketing made in Nigeria products in the global market. European Journal of Social Sciences, $16(2), 175$.

Organisation for Economic Co-Operation and Development (OECD). (2004). For promoting entrepreneurship and innovative smes in a global economy: Towards a more responsible and inclusive globalisation. Proceedings from $2 n d$ OECD Conference of Ministers Responsible for Small And Medium-Sized Enterprises (SMEs). Paris, France.

Organization for Economic Co-Operation and Development (OECD). (2009). The impact of the global crisis on SME and entrepreneurship financing and policy responses. Centre for Entrepreneurship, SMEs and Local Development.

Penrose, E. (1995). The theory of the growth of the firm. Oxford: Oxford University Press.

Sana, A. U., \& Abbas, A. A. (2005). The SME sector in Iraq: A key resource to short-term income generation and longer-term development. International Labour Office Geneva.

Sobri Minai, M., \& Lucky, E. O. I. (2011). The moderating effect of location on small firm performance: Empirical evidence. International Journal of Business and Management, 6(10), 178.

Stainer, L. (2006). Performance management and corporate social responsibility: The strategic connection. Strat. Change, 15, 253-264.

Tambunan, T. (2005). Promoting small and medium enterprises with a clustering approach: A policy experience from Indonesia. Journal of Small Business Management, 43(2), 138-154.

United States Agency for International Development (USAID). (2009). Iraq economic recovery assessment. USAID.

United States Agency for International Development (USAID). (2010). Investor guide to Iraq. USAID.

United States Agency for International Development USAID. (2011). State of Iraq's microfinance industry. USAID.

Wamono, R. N., Kikabi, P., \& Mugisha, J. (2012). Constraints and opportunities for SMEs investment in Uganda's oil and gas sector. Investment Climate and Business Environmental Research Fund.

Wheelen, T. L., \& Hunger, D. J. (1995). Strategic management and business policy. Massachusetts: Addison-Wesley Publishing Company.

Yamin, S., Gunasekaran, A., \& Mavondo, F. T. (1999). Relationship between generic strategies, competitive advantage and organizational performance: An empirical analysis. Technovation, 19(8), 507-518. 